\title{
ОГЛЯДОВА СТАТТЯ
}

УДК 614.2:061.1(100)ВО3(091)

DOI: $10.26565 / 2617-409 X-2021-7-10$

\section{РОЛЬ ВСЕСВІТНЬОЇ ОРГАНІЗАЦІЇ ОХОРОНИ ЗДОРОВ'Я У ВИРІШЕННІ МІЖНАРОДНИХ ПРОБЛЕМ ГРОМАДСЬКОГО ЗДОРОВ'Я: ІСТОРІЯ, СУЧАСНІСТЬ ТА ПЕРСПЕКТИВИ РОЗВИТКУ}

\author{
Загороднєва О. В., Пономарьова Л. І.
}

Пошта для листування: oksana.v.zagorodneva@karazin.ua

\begin{abstract}
Резюме. Численні епідемї віспи, холери, чуми та інших інфекиійних захворювань у світі в минулі часи супроводжувались смертями мільйонів людей та нерідко погрожували людству знищенням як біологічного виду. Тому суспільство було змушене об'єднати зусилля задля створення організації, яка б забезпечувала охорону здоров'я у світовому масштабі. Стараннями 26 держав-членів Організачії Об'єднаних Націй 7 квітня 1948 р. було створено Всесвітню організацію охорони здоров'я, головна мета якої полягала у сприянні забезпеченню охорони здоров'я населення усіх країн світу. Метою дослідження було проведення аналізу історичних даних прочесу створення Всесвітньої організації охорони здоров'я, досягнень за всі роки ї̈ існування, фінансування в останні роки та формування думки авторів о ролі иісї організаиії у виріменні проблем охорони здоров'я всього людства. Результати. У статі наведені дані про етапи становлення Всесвітньої організаиії охорони здоров'я. Надана детальна інформачія щзодо позитивних результатів діяльності протягом більше 70 років у вирішенні проблем репродуктивного здоров'я, материнської та дитячої смертності, викорінення багатьох інфекиійних захворювань у різних куточках світу тощо. Були ухвалені сумісні резолюції Всесвітньої організації охорони здоров'я з Організачією Об'єднаних Наџій, які стосувались загального і повного роззброєння, захисту людства від атомної радіації, заборони використання хімічної і бактеріологічної зброї, визначення ролі лікарів та інших працівників охорони здоров'я у збереженні і зміцненні миру. Наведена інформація про фінансування Всесвітньої організації охорони здоров'я. Висвітлені перспективи розвитку організації. Висновки. Всесвітня організація охорони здоров'я активно продовжує свою роботу - підтримує тісний контакт $з$ міжнародними експертами, урядами та партнерами для швидкого отримання наукових даних про новий вірус, відстежує його поширення та проводить оцінку вірулентності і надає країнам $і$ населенню рекомендацій про заходи щодо захисту здоров'я та попередження поширення спалаху. Загрози глобального кліматичного кризу та пандемії коронавірусної інфекції показали, щяо роль Всесвітньої організачії охорони здоров'я має зростати задля попередження можливих катаклізмів як в окремих державах, так і в світовому масштабі. I саме Всесвітня організачія охорони здоров'я, маючи величезний позитивний міжнародний досвід у боротьбі з різноманітними проблемами в галузі охорони здоров'я суспільства, залишається єдиною ефективною організаџією, яка консолідує зусилля більшості краӥн світу для подолання проблем всього людства.
\end{abstract}

Ключові слова: громадське здоров’я, Всесвітня організація охорони здоров’я

\footnotetext{
Інформація про авторів Загороднєва Оксана Володимирівна, к. мед. Н., доц. кафедри гігієни та соціальної медицини Харківського національного університету імені В. Н
}

Каразіна, майдан Свободи, 6, Харків, Україна, 61022

e-mail: oksana.v.zagorodneva@karazin.ua https://orcid.org/0000-0002-3403-4984

Пономарьова Лілія Іванівна, к. мед. н., ст. науч. співроб., доц. кафедри гігієни та соціальної медицини Харківського національного університету імені В. Н. Каразіна, майдан Свободи, 6, Харків, Україна, 61022

e-mail: liponomaryova@karazin.ua http://orcid.org/0000-0002-2300-0922

\section{Вступ}

Запобігання пандеміям та іншим серйозним ризикам для здоров'я населення вимагає розширення прав і можливостей Всесвітньої організації охорони здоров'я як в політичному,

так і в економічному плані (Хав'єр Солана, президент Центру глобальної економіки та геополітики ESADE, фахівець у галузі зовнішньої політики університету Брукінгса) [1]. 
Актуальні проблеми сучасної медицини. Випуск 7, 2021

Метою дослідження було провести аналіз історичних даних процесу створення Всесвітньої організації охорони здоров'я, досягнень за всі роки іiі існування, фінансування в останні роки та формування думки авторів о ролі цієї організації у вирішенні проблем охорони здоров'я всього людства.

Матеріали і методи дослідження: аналіз і узагальнення даних сучасної наукової літератури з проблем діяльності Всесвітньої організації охорони здоров'я.

\section{Результати та обговорення}

Численні епідемії віспи, холери, чуми та інших інфекційних захворювань у світі в минулі часи супроводжувались смертями мільйонів людей та нерідко погрожували людству знищенням як біологічного виду. Тому суспільство було змушене об'єднати зусилля задля створення організації, яка б забезпечувала охорону здоров'я у світовому масштабі. У 1851 р. представники 12 держав (Австрії, Англії, Іспанії, Франції та ін.) у Парижі провели Першу міжнародну санітарну конференцію, де розробили i прийняли Міжнародний карантинний статут [2].

Згодом, у 1902 p., на конференції у Вашингтоні було створено Міжнародне (Панамериканське) санітарне бюро, яке у 1958 р. реорганізовано у Панамериканську організацію охорони здоров'я.

Наступним важливим кроком на шляху розвитку міжнародної співпраці стало створення у 1907 p. в Парижі Міжнародного бюро громадської гігієни, завдання якого було збір та доведення до відома країн-учасниць інформації щодо охорони здоров'я населення та заходів боротьби з епідеміями [3].

У зв'язку з різким погіршенням епідемічної ситуації в Європі у 1923 р. міжнародним співтовариством була заснована Організація охорони здоров'я Ліги Націй. Ї̈і мета полягала у прийнятті заходів міжнародного масштабу щодо попередження та боротьби з хворобами [4].

Після Другої світової війни, у 1945 р., за ініціативою країн-переможниць створюється Організація Об'єднаних Націй $(\mathrm{OOH})$, яка стає провідною організацією міжнародного співтовариства. У 1946 р. конференція ООН ухвалила рішення про необхідність створення спеціалізованої установи ООН з питань охорони здоров'я населення. У тому ж році у Нью-Йорку на міжнародній конференції розроблено та затверджено Статут нової міжнародної організації охорони здоров'я - Всесвітньої організації охорони здоров'я - BOO3 (World Health Organization - WHO). У документі проголошено основні принципи співробітництва держав-членів Організації, визначено поняття «здоров'я», як «стану повного фізичного, душевного і соціального благополуччя, а не тільки відсутність хвороб або фізичних дефектів...» та зазначено, що «уряди держав несуть відповідальність за здоров'я своїх народів, і ця відповідальність вимагає прийняття відповідних заходів соціального характеру в галузі охорони здоров'я» [5].

До 7 квітня 1948 р. 26 держав-членів ООН прийняли Статут ВООЗ та ратифікували його. Тому цей день -7 квітня - вважається датою створення організації і щорічно відзначається у світі як День здоров'я. Місцем штаб-квартири ВООЗ обрано Женеву.

Головною метою ВОО3 $є$ сприяння забезпеченню охорони здоров'я населення усіх країн світу. Текст ії Статуту (Конституції) можна коротко сформулювати як «Право на здоров'я».

Сьогодні ВОО3 координує міжнародне співробітництво 3 метою розвитку й удосконалення національних систем охорони здоров'я, викорінення інфекційних захворювань, впровадження загальної імунізації, попередження та боротьби 3 неінфекційними захворюваннями. Також пріоритетними напрямами визначені охорона здоров'я матері і дитини, охорона й оздоровлення навколишнього середовища, розвиток медикобіологічних досліджень, підготовка медичних кадрів, координація фармацевтичної діяльності країн-членів організації. Особлива увага приділяється санітарній статистиці [6].

Впродовж останніх років завдяки зусиллям ВОО3 питання охорони здоров'я стали пріоритетом у політичному порядку денному світу. Їх почали обговорювати на найважливіших політичних форумах. Особливо цьому посприяла пандемія COVID19.

3 часу свого створення ВООЗ внесла вагомий внесок в досягнення багатьох історично значимих успіхів в області охорони 
Actual problems of modern medicine. Issue 7, 2021

здоров'я населення світу. 31948 р. і до сьогодні продовжується удосконалення Міжнародної класифікації хвороб, яка є єдиним міжнародним стандартом і застосовується для клінічних та епідеміологічних спостережень. 3 1950 р. фахівці ВООЗ беруть участь у розробці рекомендацій щодо використання антибіотиків. У 1954-64 роках вдало виконано Глобальну програму 3 ліквідації тропічної гранульоми (у країнах Африки): розповсюдженість цього захворювання зменшилась на 95 \%. У 1958-80 роках успішно втілено Глобальну ініціативу 3 ліквідації натуральної віспи: завдяки 20-річній кампанії 3 вакцинації населення, проведеної під керівництвом ВОО3, вдалося добитися іiї повного викорінення. У 1974-2002 роках ефективно проведена робота 3 ліквідації онхоцеркозу («річкової сліпоти») переважно у країнах Африки $[7,8]$.

З 1977 p. ВОО3 ініціювала міжнародну кампанію під назвою "Здоров`я для всіх", у межах якої розпочато збір і систематизацію інформації про існуючі загрози здоров ю. За підсумками роботи було скликано Міжнародну конференцію 3 першочергових заходів щодо охорони здоров`я (Алма-Ата, 1978 р.), яка проголосила відповідну Декларацію [9].

Глобальна стратегія "Здоров`я для всіх до 2000 року" містила 10 положень, 6 принципів і 38 завдань, спрямованих на попередження загрози здоров ю. Цілі і принципи цієї стратегії визначили ті ідеологічні напрями, за якими мала визначатися діяльність ВОО3 у наступні роки: просвітницька робота, пов'язана із роз'ясненням суті проблем охорони здоров'я; належне забезпечення продуктами харчування; безпечна для здоров'я вода та санітарія; охорона здоров'я матері та дитини, включаючи планування сім'ї; імунізація населення від основних інфекційних хвороб; профілактика місцевих захворювань та контроль над ними; належне лікування загально розповсюджених хвороб та травм та ін. [10]

Значні надбання ВОО3 в сфері охорони громадського здоров'я були отримані і надалі. 80-ті роки XX сторіччя були проголошені Міжнародним десятиліттям постачання населенню безпечної для здоров'я питної води та санітарії, ліквідації відходів відповідно до санітарних вимог.
31988 р. здійснюється Глобальна ініціатива 3 ліквідації поліомієліту - завдяки поширенню вакцинації населення кількість випадків цього захворювання у всьому світі скоротилася більш ніж на $99 \%$ і в 2002 р. відбулося підтвердження статусу Європейського регіону як вільного від поліомієліту [11].

Протягом всього часу існування $\mathrm{BOO} 3$ важливе місце в іii роботі займали соціальнополітичні питання (сумісні резолюції ВООЗ 3 $\mathrm{OOH})$, які стосувались загального і повного роззброєння (1960р.), захисту людства від атомної радіації (1961 p.), заборони використання хімічної і бактеріологічної зброї (1970 р.), визначення ролі лікарів та інших працівників охорони здоров'я у збереженні і зміцненні миру (1979, 1981, 1983 роки) тощо.

У 2000 р. на саміті ООН керівники 189 держав ухвалили Декларацію тисячоліття і програму в галузі розвитку світового суспільства: план спільної роботи країн 3 метою зменшення масштабів бідності, голоду, поліпшення якості освіти і забезпечення гендерної рівності, зменшення смертності серед дітей віком до п'яти років на дві третини, поліпшення здоров'я матерів шляхом зниження рівня материнської смертності на три чверті, задоволення потреб у загальному доступі до отримання допомоги у сфері репродуктивного здоров'я, гарантія доступу до чистої води та екологічної безпеки, обмеження поширення ВІЛ-інфекції, малярії та туберкульозу i започаткування тенденції до скорочення їх масштабів $[12,13]$.

Робота над виконанням цієї програми завершилася у 2015 р. Досягнуто величезних успіхів у зниженні дитячої смертності (до 50 \%), зміцненні материнського здоров'я та боротьбі проти ВІЛ-інфекції (кількість нових випадків інфікування знизилася на 40 \%), Європейський регіон було оголошено вільним від малярії $[14,15,16]$.

У 2015 p. Генеральна Асамблея ООН підвела підсумки виконання програми «Цілі розвитку тисячоліття» та прийняла амбіційну резолюцію, у якій затверджено новий план дій - «Перетворення нашого світу: Порядок денний в сфері сталого розвитку на період до 2030 року». У документі підкреслювалось, що ніколи раніше світові лідери не брали на себе зобов'язання щодо об'єднання зусиль для 
Актуальні проблеми сучасної медицини. Випуск 7, 2021

реалізації такої широкої та універсальної стратегічної програми. Відзначено прагнення здійснювати завдання таким чином, щоб це принесло максимальну користь як нинішньому, так і майбутнім поколінням на принципах відповідності міжнародному праву. Всі 17 цілей та 169 задач нового плану дій набули чинності 01.01.2016 p. Основними з них $€$ : повсюдне викорінення бідності, голоду, досягнення продовольчої безпеки, сприяння сталому розвитку сільського господарства; забезпечення здорового способу життя; забезпечення інклюзивної та якісної освіти; забезпечення гендерної рівності; сприяння безперервному, сталому економічному зростанню; зменшення нерівності всередині країн i між країнами; впровадження невідкладних заходів 3 боротьби зі зміною клімату i iii наслідками; зміцнення, імплементація та активізація глобального партнерства і співпраці для сталого розвитку та iн. [17].

Робота над цим планом дій розрахована на 15 років - до 2030 року.

У 2012 р. Свропейський регіональний комітет ВООЗ затвердив політику «Здоров'я-2020». Всі 53 держави-члена Європейського регіону ВООЗ ухвалили рішення про створення нових спільних основ політики громадського здоров'я.

В основу політики «Здоров'я-2020» закладено ідею, що держава зможе домогтися реальних поліпшень у стані здоров'я населення, якщо вона на всіх рівнях і у всіх секторах державного управління буде вирішувати взаємопов'язані стратегічні завдання: поліпшення здоров'я для всіх і зменшення нерівностей у відношенні здоров'я; вдосконалення лідерства та колективного керівництва в інтересах здоров'я [18].

У період з 2019 по 2023 роки ключовим принципом роботи ВООЗ $є$ «забезпечення здорового способу життя та сприяння благополуччю для всіх у будь-якому віці». Для досягнення цього основна увага приділяється трьом стратегічним пріоритетам («цілі на три мільярди»): поліпшення доступу до загального медичного страхування для 1 мільярда чоловік; гарантування якісного медичного обслуговування у разі надзвичайних ситуацій для 1 мільярда чоловік; підвищення рівня добробуту та якості здоров'я для 1 мільярда чоловік [19].
Незважаючи на прогрес у виконанні Цілей тисячоліття, щороку понад 6 мільйонів дітей не доживають до свого п'ятого дня народження. Щодня гинуть 16000 дітей від хвороб, які можна попередити (кір, туберкульоз). Сотні жінок щодня помирають під час вагітності або від ускладнень під час пологів. У багатьох сільських районах лише 56 \% пологів приймають кваліфіковані фахівці. Основною причиною смерті серед підлітків у країнах Африки на південь від Сахари $\epsilon$ ВІЛ-інфекція [20].

Ситуацію можна виправити шляхом покращення освіти, профілактики (у тому числі імунізації), діагностики та лікування захворювань i впровадження цільових програм 3 охорони сексуального та репродуктивного здоров'я. Необхідно залучати науковий світ для проведення досліджень та розробок вакцин.

Протягом календарного року ВООЗ проводить Глобальні кампанії з охорони здоров'я задля поширення інформаційної обізнаності населення щодо конкретних медико-соціальних проблем: Всесвітній день боротьби проти туберкульозу 24 березня; Всесвітній день здоров'я - 7 квітня; Всесвітній тиждень імунізації- останній тиждень квітня; Всесвітній день боротьби з малярією - 25 квітня; Всесвітній день без тютюну - 31 травня; Всесвітній день донора крові - 14 червня; Всесвітній день боротьби з гепатитом - 28 липня; Всесвітній день боротьби зі СНІДом - 1 грудня; Всесвітній день психічного здоров'я - 10 жовтня; Всесвітній тиждень правильного використання антибіотиків - листопад.

Такі масштабні кампанії, як і інша глобальна діяльність ВОО3, вимагають величезних фінансових витрат.

В організації існують два основних джерела доходів - обов'язкові та добровільні внески. Перші формуються 3 урахуванням валового внутрішнього продукту кожної країни, $\epsilon$ членськими внесками і покривають менше $20 \%$ сукупного бюджету ВООЗ. Інші складаються 3 пожертвувань країн-учасниць i неурядових організацій [21].

Кожного року Всесвітня асамблея охорони здоров'я, яка $є$ керівним органом ВООЗ і налічує 194 країни-члена, ухвалює програмний бюджет, у якому відображений план використання фінансових ресурсів. Так, дворічний бюджет на 2020-2021 роки становить 4,84 млрд. доларів США [22]. У 2018-2019 роках обов'язкові внески 
Actual problems of modern medicine. Issue 7, 2021

склали 956,9 млн. доларів США (17 \% доходів), а добровільні - 4,49 млрд. доларів США (80 \% доходів, рис.1) [23].
Основними фінансовими донорами ВООЗ є США, Фонд Білла i Мелінди Гейтс, Великобританія, Німеччина (рис.2) [24].

Figure 1

\section{World Health Organization (WHO) Revenue by Type, 2018- 2019}

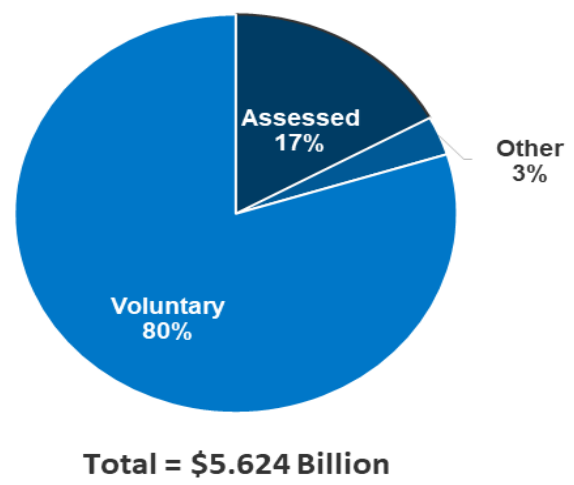

NOTES: Voluntary includes specified and core voluntary contributions. Other includes PIP contributions

SOURCES: WHO "Contributors - Funding by funding type, 2018-2019" a

Рис. 1. Основні джерела доходів ВООЗ у 2018-2019 роках

Top 20 contributors to the Programme budget 2018 (US\$ thousands)

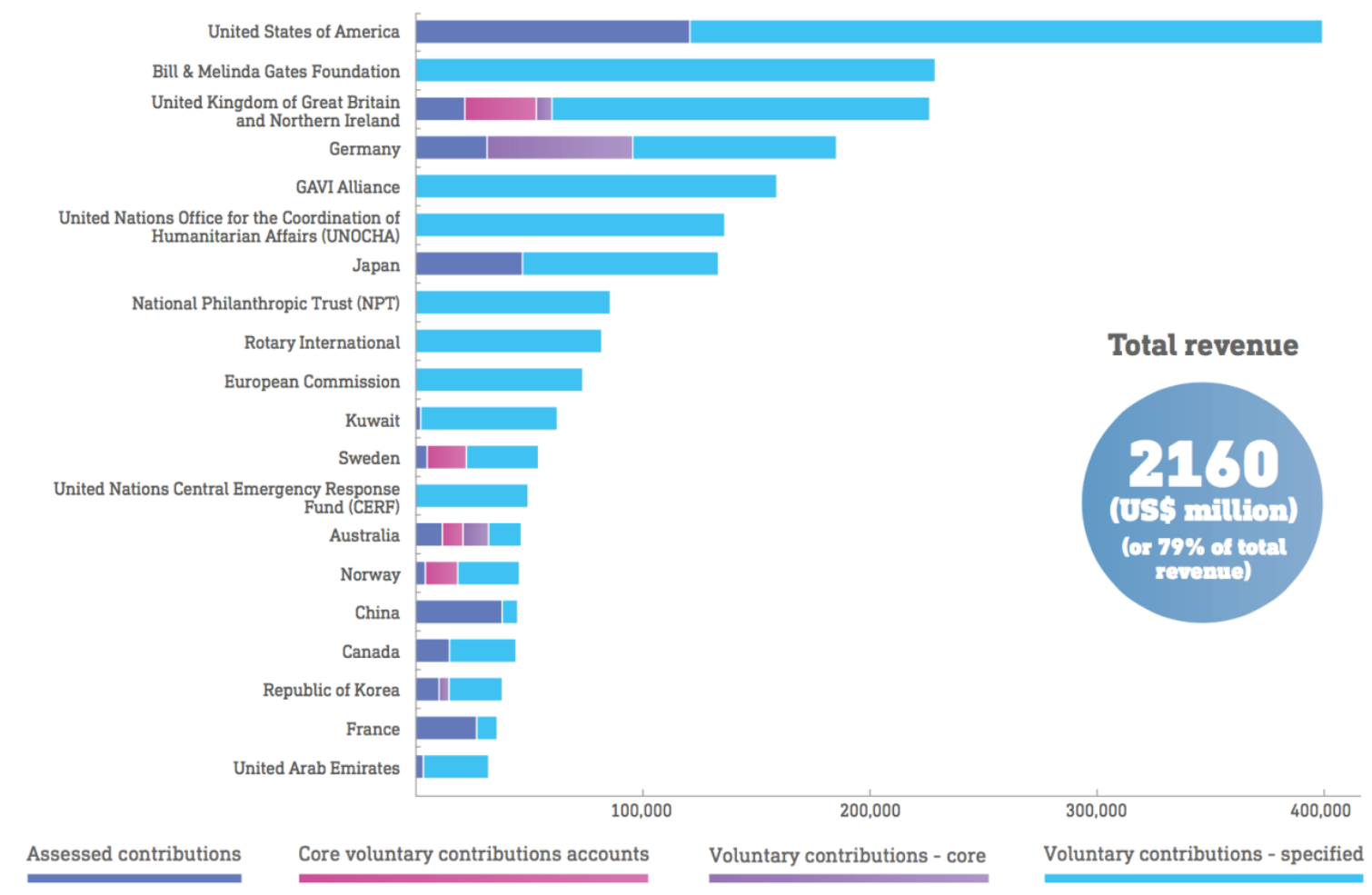

Рис. 2. Найбільші учасники Програмного бюджету ВООЗ у 2018 р. (у тис. доларів США)

Навесні 2020 р. президент США Дональд Трамп заявив про припинення фінансування
ВООЗ, звинувативши іï в підтримці Китаю в умовах пандемії коронавірусу [25]. 
Актуальні проблеми сучасної медицини. Випуск 7, 2021

На 31 березня 2020 р. більше половини несплачених членських внесків припадає на США (196 млн. доларів США) та Китай (57 млн. доларів США). Країни-боржники згодом втрачають право голосу в Асамблеї ВООЗ. У 2019 р. це сталося з Центральноафриканською Республікою, Коморськими Островами, Гвінеєю-Бісау, Південним Суданом, Гамбією, Україною та Венесуелою. Можливе повернення права голосу при умовах поступового погашення боргу, як це сталося зі Сомалі [26].

Останнім часом у засобах масової інформації нерідко можна зустріти висловлювання про сумнівну роль ВООЗ як «керівного i координуючого органу в міжнародній роботі в галузі охорони здоров'я» у зв'язку 3 недавніми частими фінансовими проблемами у результаті надмірної залежності від добровільного короткострокового фінансування 3 боку донорів [27, 28]. Так, BOO3 зараз переживає важкі часи - труднощі 3 фінансуванням, прозорістю механізмів розподілу ресурсів, нові виклики з подолання пандемії коронавірусної інфекції та інші. Однак, незважаючи на це, організація активно продовжує свою роботу - підтримує тісний контакт з міжнародними експертами, урядами та партнерами для швидкого отримання наукових даних про новий вірус, відстежує його поширення та проводить оцінку вірулентності і надає країнам i населенню рекомендацій про заходи щодо захисту здоров'я та попередження поширення спалаху.

\section{Висновки}

Загрози глобального кліматичного кризу та пандемія коронавірусної інфекції показали, що роль ВОO3 має зростати задля попередження можливих катаклізмів як в окремих державах, так і в світовому масштабі. Для того щоб покласти край глобальній пандемії, світ повинен об'єднати зусилля не менше, ніж в глобальних масштабах. Це історичне випробування для глобального співробітництва. I саме ВОО3, маючи величезний позитивний міжнародний досвід у боротьбі з різноманітними проблемами в галузі охорони здоров'я суспільства, залишається єдиною ефективною організацією, яка консолідує зусилля більшості країн світу для подолання проблем всього людства.

\section{Список літератури}

1. Cuesto M, Brown TM, Fee E. The World Health Organization. A History. Cambridge University Press. 2019. https://www.researchgate.net/publication/331772951_The_World _Health_Organization_A_History

2. J. Solana. A better globalization. The Global Leadership Foundation. 2020 Jul 21. https://www.g-l-f.org/who-we-are/glfmembers-listed-by-region/javier-solana/a-better-globalization/

3. Сорокина ТС. История медицины: учебник. М.: Академия, 2008: 560 с.

4. Едді Н. Орінда Генезис міжнародно-правового співробітництва в боротьбі 3 епідеміями та пандеміями. European political and law discourse. 2016; 3(4): 43-47. https://eppd13.cz/wp-content/uploads/2016/2016-3-4/07.pdf

5. Скрипник ОМ. Історія міжнародних організацій: навчальний посібник. Умань: ПП Жовтий ОО. 2011: 226 с. https://dspace.udpu.edu.ua/bitstream/6789/790/1/Istoriya_mizhnar odnykh_orhanizatsiy.pdf

6. Всесвітня організація охорони здоров'я. Постійне представництво України при відділенні $\mathrm{OOH}$ та інших міжнародних організаціях у Женеві. 2012 жовт 16. https://geneva.mfa.gov.ua/posolstvo/2612-who

7. WHO revives efforts to eliminate forgotten disease. World Health Organization. 2007 Jan 25. https://www.who.int/mediacentre/news/notes/2007/np04/en/

8. Onchocerciasis. World Health Organization. 2019 Jun 14 https://www.who.int/news-room/fact-sheets/detail/onchocerciasis

9. History of Smallpox. Centers for Disease Control and $\begin{array}{llll}\text { Prevention } & \text { (CDC). } & 2021 & \text { Febr }\end{array}$ https://www.cdc.gov/smallpox/history/history.html

10. Гладун 3С. Державна політика охорони здоров'я в Україні (адміністративно-правові проблеми формування i реалізації): Монографія. Тернопіль: Економічна думка, 2005: 460 c. http://library.wunu.edu.ua/files/EVD/mg_dpozou.pdf

11. Eradicating polio. Unicef for every child. https://www.unicef.org/immunization/polio

12. Декларація тисячоліття Організації Об'єднаних Націй. Верховна Рада України. Документ 995_621, прийняття від 08.09.2000. https://zakon.rada.gov.ua/laws/show/995_621\#Text

13. Sustainable Development Goals 2015-2030. United Nations Development Programme.

https://www.ua.undp.org/content/ukraine/en/home/sustainabledevelopment-goals.html

14. Suzuki E, Kashiwase H. Despite remarkable progress, 15000 children and 800 women still die every day mostly of preventable or treatable causes. World Bank Blogs. 2019 Sept 19. https://blogs.worldbank.org/opendata/despite-remarkableprogress-15000-children-and-800-women-still-die-every-daymostly

15. Global HIV \& AIDS statistics - 2020 fact sheet. UNAIDS. 2020. https://www.unaids.org/en/resources/fact-sheet

16. The WHO European Region remains malaria free. World Health Organization. $\quad 2017 \quad$ Apr 25. https://www.euro.who.int/en/health-topics/communicable-

diseases/vector-borne-and-parasitic-

diseases/news/news/2017/04/the-who-european-region-remainsmalaria-free

17. Transforming our World: The 2030 Agenda for Sustainable Development. United Nations. 2015: 41 p. https://sustainabledevelopment.un.org/post2015/transformingourw orld/publication

18. Слабкий ГО, Пархоменко ГЯ, Астахова НЮ. Здоров'я 2020 - нова європейська політика і стратегія в інтересах здоров'я населення. Вістник проблем біології і медицини. 2014; Вип. 3, Т.1 (110): 16-20. https://vpbm.com.ua/ua/vpbm2014-03-1/6408 
Actual problems of modern medicine. Issue 7, 2021

19. Thirteenth General Programme of Work 2019-2023. World Health Organization. 2020. https://www.who.int/about/what-wedo/thirteenth-general-programme-of-work-2019---2023

20. Leaders from around the world are All In to end the AIDS epidemic among adolescents. 2015 Febr 17. https://www.unaids.org/en/allin

21. Money talks at the world health organization. The War on Drugs. Section D1. 2017: 243-262. https://phmovement.org/wpcontent/uploads/2018/07/D1.pdf

22. World Health Organization: what does it spend its money on? The Conversation Trust (UK) Limited. 2020 Apr 23 https://theconversation.com/world-health-organization-what-doesit-spend-its-money-on-136544

23. The U.S. Government and the World Health Organization. Kaiser Family Foundation. 2021 Jan 25. https://www.kff.org/coronavirus-covid-19/fact-sheet/the-u-sgovernment-and-the-world-health-organization/

24. How is the World Health Organization funded? World $\begin{array}{llll}\text { Economic } & \text { Forum. } & 2020 & \text { Apr }\end{array}$ https://www.weforum.org/agenda/2020/04/who-funds-worldhealth-organization-un-coronavirus-pandemic-covid-trump/ 25. Joseph A, Branswell H. Trump: U.S. will terminate relationship with the World Health Organization in wake of Covid19 pandemic. STAT. 2020 May 29. https://www.statnews.com/2020/05/29/trump-us-terminate-whorelationship/

26. Parker B. WHO's members owe it more than $\$ 470$ million. The New Humanitarian. 2020 Apr 30 https://www.thenewhumanitarian.org/maps-and-

graphics/2020/04/30/world-health-organisation-funding

27. Чи потрібна світові BООЗ. Zbruc. 2020 Лип 10. https://zbruc.eu/node/98952

28. Reddy SK, Mazhar S, Lencucha R. The financial sustainability of the World Health Organization and the political economy of global health governance: a review of funding proposals. Globalization and Health. BioMed Central Ltd unless otherwise stated. Part of Springer Nature. 2018 Nov 29 https://globalizationandhealth.biomedcentral.com/articles/10.1186 /s12992-018-0436-8

\section{References}

1. Cuesto M, Brown TM, Fee E. The World Health Organization. A History. Cambridge University Press. 2019. https://www.researchgate.net/publication/331772951_The_World _Health_Organization_A_History

2. J. Solana. A better globalization. The Global Leadership Foundation. 2020 Jul 21. https://www.g-l-f.org/who-we-are/glfmembers-listed-by-region/javier-solana/a-better-globalization/

3. Sorokina TS. History of medicine: textbook. M.: Academy, 2008: 560 p. [in Russian]

4. Eddy N. Orinda Genesis of international legal cooperation in combating epidemics and pandemics. European political and law discourse. 2016; 3(4): 43-47. https://eppd13.cz/wpcontent/uploads/2016/2016-3-4/07.pdf [in Ukrainian]

5. Skripnik OM. History of international organizations: textbook. Uman: PE Zhovtiy OO. 2011: 226 p. https://dspace.udpu.edu.ua/bitstream/6789/790/1/Istoriya_mizhnar odnykh_orhanizatsiy.pdf [in Ukrainian]

6. World Health Organization. Permanent Mission of Ukraine to the UN Office and other International Organizations in Geneva. 2012 oct 16. https://geneva.mfa.gov.ua/posolstvo/2612-who

7. WHO revives efforts to eliminate forgotten disease. World Health Organization. 2007 Jan 25. https://www.who.int/mediacentre/news/notes/2007/np04/en/ 8. Onchocerciasis. World Health Organization. 2019 Jun 14. https://www.who.int/news-room/fact-sheets/detail/onchocerciasis
9. History of Smallpox. Centers for Disease Control and Prevention (CDC). $2021 \quad$ Febr 20. https://www.cdc.gov/smallpox/history/history.html

10. Gladun ZS. State health policy in Ukraine (administrative and legal problems of formation and implementation): textbook. Ternopil: Ekonomichna dumka, 2005: 460 p. http://library.wunu.edu.ua/files/EVD/mg_dpozou.pdf [in Ukrainian]

11. Eradicating polio. Unicef for every child. https://www.unicef.org/immunization/polio

12. United Nations Millennium Declaration. Verkhovna Rada of Ukraine. Document 995_621, approval 08.09.2000. https://zakon.rada.gov.ua/laws/show/995_621\#Text [in Ukrainian] 13. Sustainable Development Goals 2015-2030. United Nations Development Programme. https://www.ua.undp.org/content/ukraine/en/home/sustainabledevelopment-goals.html

14. Suzuki E, Kashiwase H. Despite remarkable progress, 15000 children and 800 women still die every day mostly of preventable or treatable causes. World Bank Blogs. 2019 Sept 19. https://blogs.worldbank.org/opendata/despite-remarkableprogress-15000-children-and-800-women-still-die-every-daymostly

15. Global HIV \& AIDS statistics - 2020 fact sheet. UNAIDS 2020. https://www.unaids.org/en/resources/fact-sheet

16. The WHO European Region remains malaria free. World Health Organization. $2017 \quad$ Apr 25. https://www.euro.who.int/en/health-topics/communicablediseases/vector-borne-and-parasitic-

diseases/news/news/2017/04/the-who-european-region-remainsmalaria-free

17. Transforming our World: The 2030 Agenda for Sustainable Development. United Nations. 2015: 41 p. https://sustainabledevelopment.un.org/post2015/transformingourw orld/publication

18. Slabkiy GO, Parhomenko GY, Astahova NY. Health 2020 New European Policy and Strategy In the Interest of Health Population. Bulletin of problems in biology and medicine. 2014; Issue 3 (110): 16-20. https://vpbm.com.ua/ua/vpbm-2014-03$1 / 6408$ [in Ukrainian]

19. Thirteenth General Programme of Work 2019-2023. World Health Organization. 2020. https://www.who.int/about/what-wedo/thirteenth-general-programme-of-work-2019---2023

20. Leaders from around the world are All In to end the AIDS epidemic among adolescents. 2015 Febr 17. https://www.unaids.org/en/allin

21. Money talks at the world health organization. The War on Drugs. Section D1. 2017: 243-262. https://phmovement.org/wpcontent/uploads/2018/07/D1.pdf

22. World Health Organization: what does it spend its money on? The Conversation Trust (UK) Limited. 2020 Apr 23. https://theconversation.com/world-health-organization-what-doesit-spend-its-money-on-136544

23. The U.S. Government and the World Health Organization. Kaiser Family Foundation. 2021 Jan 25. https://www.kff.org/coronavirus-covid-19/fact-sheet/the-u-sgovernment-and-the-world-health-organization/

24. How is the World Health Organization funded? World $\begin{array}{llll}\text { Economic } & \text { Forum. } & 2020 & \text { Apr }\end{array}$ https://www.weforum.org/agenda/2020/04/who-funds-worldhealth-organization-un-coronavirus-pandemic-covid-trump/ 25. Joseph A, Branswell H. Trump: U.S. will terminate relationship with the World Health Organization in wake of Covid19 pandemic. STAT. 2020 May 29. https://www.statnews.com/2020/05/29/trump-us-terminate-whorelationship/ 
Актуальні проблеми сучасної медицини. Випуск 7, 2021

26. Parker B. WHO's members owe it more than $\$ 470$ million. The New Humanitarian. 2020 Apr 30. https://www.thenewhumanitarian.org/maps-andgraphics/2020/04/30/world-health-organisation-funding 27. Does the world need a World Health Organization. Zbruc. 2020 July 10. https://zbruc.eu/node/98952 [in Ukrainian]
28. Reddy SK, Mazhar S, Lencucha R. The financial sustainability of the World Health Organization and the political economy of global health governance: a review of funding proposals. BioMed Central Ltd unless otherwise stated. Part of Springer Nature. 2018 Nov 29. https://globalizationandhealth.biomedcentral.com/articles/10.1186 /s12992-018-0436-8

\title{
THE ROLE OF THE WORLD HEALTH ORGANIZATION IN SOLVING INTERNATIONAL PUBLIC HEALTH PROBLEMS: HISTORY, MODERNITY AND DEVELOPMENT PROSPECTS
}

\author{
Zahorodnieva Oksana, Ponomaryova Liliya
}

Mail for correspondence: oksana.v.zagorodneva@karazin.ua

Summary. Epidemics of smallpox, cholera, plague and other infectious diseases in the world in the past were accompanied by the deaths of millions of people and often threatened humanity with destruction as a biological species. Therefore, society was forced to join forces to create an organization that would provide health protection on a global scale. On April 7, 1948, 26 UN member states created the World Health Organization, the main goal of which was to help provide the protection of health of the population of all countries of the world. Purpose of the study - analysis of the historical data of the process of creating the World Health Organization, achievements for all the years of its existence, financing in last years and formation of the opinions of authors on the role of this organization in solving health problems of all humanity. Results. The article presents data on stages of the formation of the World Health Organization. Information about positive results for more than 70 years in solving reproductive health problems, maternal and child mortality, eradicating many infectious diseases in different parts of the world and other problems is detailed. Joint resolutions of the World Health Organization with the United Nations were adopted about general and complete disarmament, protection of humanity from atomic radiation, ban on the use of chemical and bacteriological weapons, defining of the role of doctors and other health workers in the preservation and strengthening of the world. Information on the World Health Organization funding is provided. The prospects for the development of the organization are described. Conclusions. The World Health Organization actively continues its work - maintains contact with international experts, governments and partners for quick collection of scientific data on a new virus, tracks its distribution and assesses its virulence, provides to countries and population recommendations on health protection measures and preventing the spread of infection. The global climatic crisis and the coronavirus infection pandemic showed that the role of the World Health Organization should increase to prevent cataclysms in some countries and globally. It is the World Health Organization that has a huge positive international experience in fighting various public health problems and it remains the only effective organization that consolidates the efforts of most countries of the world to overcome the problems of all humanity.

Keywords: public health, World Health Organization

Information about authors

Zahorodnieva Oksana, PhD, Associate Professor of department of hygiene and social medicine, V. N. Karazin Kharkiv National University, Svobody Square, 6, Kharkiv, Ukraine, 61022 e-mail: oksana.v.zagorodneva@karazin.ua https://orcid.org/0000-0002-3403-4984

Ponomaryova Liliya, PhD, Senior Researcher, Associate Professor of department of hygiene and social medicine, V. N. Karazin Kharkiv National University,
Svobody Square, 6, Kharkiv, Ukraine, 61022

e-mail: liponomaryova@karazin.ua http://orcid.org/0000-0002-2300-0922 
Actual problems of modern medicine. Issue 7, 2021

\title{
РОЛЬ ВСЕМИРНОЙ ОРГАНИЗАЦИИ ЗДРАВООХРАНЕНИЯ В РЕШЕНИИ МЕЖДУНАРОДНЫХ ПРОБЛЕМ ОБЩЕСТВЕННОГО ЗДОРОВЬЯ: ИСТОРИЯ, СОВРЕМЕННОСТЬ И ПЕРСПЕКТИВЫ РАЗВИТИЯ
}

\author{
Загороднева О. В., Пономарева Л. И.
}

Почта для переписки: oksana.v.zagorodneva@karazin.ua

\begin{abstract}
Резюме. Многочисленные эпидемии оспы, холеры, чумы и других инфекционных заболеваний в мире в прошлом сопровождались смертями миллионов людей и нередко угрожсали человечеству уничтожением как биологического вида. Поэтому общество было вынуждено объединить усилия для создания организачии, которая бы обеспечивала охрану здоровья в мировом масштабе. Стараниями 26 государств-членов ООН 7 апреля 1948 г. была создана Всемирная организация здравоохранения, главная иель которой заключалась в содействии обеспечению охраны здоровья населения всех стран мира. Цель исследования - анализ исторических данных проиесса создания Всемирной организации здравоохранения, достижений за все годы ее существования, финансирования в последние годы и формирование мнения авторов о роли этой организации в решении проблем здравоохранения всего человечества. Результаты. В статье приведены данные об этапах становления Всемирной организации здравоохранения. Предоставлена подробная информация о положительных результатах деятельности в течение более 70 лет в решении проблем репродуктивного здоровья, материнской и детской смертности, искоренения многих инфекиионных заболеваний в разных уголках мира и тому подобном. Были приняты совместные резолючии Всемирной организащии здравоохранения с Организащией Объединенных Наџий, касающиеся всеобщего и полного разоружения, защиты человечества от атомной радиации, запрета на использование химического и бактериологического оружия, определения роли врачей и других работников здравоохранения в сохранении и укреплении мира. Приведена информация о финансировании Всемирной организачии здравоохранения. Освещены перспективы развития организации. Выводы. Всемирная организация здравоохранения активно продолжает свою работу - поддерживает тесный контакт с межсународными экспертами, правительствами и партнерами для быстрого получения научных данных о новом вирусе, отслеживает его распространение и проводит оценку вирулентности, предоставляет странам и населению рекомендащии о мерах по защите здоровья и предупреждению распространения вспышки. Угрозы глобального климатического кризиса и пандемии коронавирусной инфекции показали, что роль Всемирной организачии здравоохранения должна расти для предупреждения возможных катаклизмов как в отдельных странах, так и в мировом масштабе. И именно Всемирная организация здравоохранения, имея огромный положительный международный опыт в борьбе с различными проблемами в области общественного здравоохранения, остается единственной эффективной организачией, которая консолидирует усилия большинства стран мира для преодоления проблем всего человечества.
\end{abstract}

Ключевые слова: общественное здоровье, Всемирная организация здравоохранения

Информация об авторах

Загороднева Оксана Владимировна, к. мед. н., доц. кафедры гигиены и социальной медицины Харьковского национального университета имени В. Н. Каразина, площадь Свободы, 6, Харьков, Украина, 61022 e-mail: oksana.v.zagorodneva@karazin.ua https://orcid.org/0000-0002-3403-4984 Пономарева Лилия Ивановна, к. мед. н., ст. науч. співроб., доц. кафедры гигиены и социальной медицины Харьковского национального университета имени В. Н. Каразина, площадь Свободы, 6, Харьков, Украина, 61022

e-mail: liponomaryova@karazin.ua http://orcid.org/0000-0002-2300-0922

Отримано: 25.03 .2021 p. Прийнято до друку: 15.05.2021 p

Conflicts of interest: author has no conflict of interest to declare.

Конфлікт інтересів: відсутній.

Конфликт интересов: отсутствует. 